\title{
Clean intermittent catheterization in patients with spinal cord injury: knowledge of nurses
}

\section{Cateterismo intermitente limpo no paciente com lesão medular: conhecimento dos enfermeiros}

\section{Cateterismo intermitente limpio en el paciente con lesión de la médula espinal: conocimiento de los enfermeros}

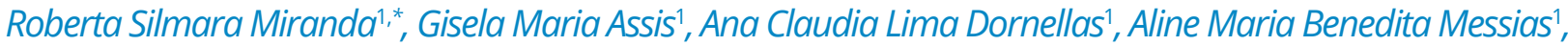
Valeria Teles Batista ${ }^{1}$, João Júnior Gomes ${ }^{1}$
\end{abstract}

ORCID IDs

Miranda RS (1D https://orcid.org/0000-0003-4004-350X

Assis GM (DD https://orcid.org/0000-0001-6343-8075

Dornellas ACL (D) https://orcid.org/0000-0002-3349-214X

Messias AMB (1D) https://orcid.org/0000-0002-3039-8211

Batista VT (D) https://orcid.org/0000-0001-8284-1484

Gomes J] (D) https://orcid.org/0000-0003-4171-2752

\section{HOW TO CITE}

Miranda RS; Assis GM; Dornellas ACL; Messias AMB; Batista VT; Gomes

J. Clean intermittent catheterization in patients with spinal cord injury: knowledge of nurses. ESTIMA, Braz. J. Enterostomal Ther., 18: e0220, 2020. https://doi.org/10.30886/estima.v18.828_IN

\begin{abstract}
Introduction: Spinal cord injury results in failure to empty the bladder, leaving the individual exposed to the risk of recurrent urinary tract infection, vesicoureteral reflux and even loss of renal function. Clean intermittent catheterization (CIC) is the method of choice for emptying the bladder in these cases. Although it has a simple technique, its performance should be well oriented in order to avoid complications such as infections or traumas. Guidance for the technique should be performed during the hospitalization period due to the injury and the nurse is responsible for this action. Objective: To evaluate the knowledge of nurses working in a trauma care hospital in relation to clean intermittent catheterization. Methods: Questionnaire constructed based on the guidelines of the European Association of Urological Nurses, applied to 18 nurses from a university hospital, a reference in the treatment of spinal trauma, regarding neurological dysfunction of the lower urinary tract and clean intermittent catheterization. Results: The participants presented expressive knowledge about lower urinary tract neurological dysfunction and CIC. There were errors regarding the $\mathrm{CIC}$ technique in the indication of the use of procedure gloves, in the lubrication of the catheter, collection of periodic urine cultures, use of antibiotics and in the need for instructions before discharge from hospital. Conclusion: Although the sample demonstrated knowledge on several issues related to the subject, the errors indicate the need for training and especially awareness of the responsibility of guidance before discharge from hospital.
\end{abstract}

DESCRIPTORS: Urinary catheterization; Health education; Nurse; Enterostomal therapy.

\begin{abstract}
RESUMO
Introdução: A lesão medular resulta em falha no esvaziamento da bexiga, deixando o indivíduo exposto a risco de infecção recorrente de trato urinário, refluxo vesicoureteral e até perda da função renal. O cateterismo intermitente limpo (CIL) é o método de escolha para esvaziamento da bexiga nesses casos. Apesar de ter uma técnica simples, sua realização deve ser bem orientada a fim de evitar complicações como infecções ou traumas. A orientação para a técnica deve ser realizada ainda no período de internação pela lesão, cujo responsável é o enfermeiro. Objetivo: Avaliar o conhecimento dos enfermeiros que atuam em hospital de atendimento ao trauma com relação ao cateterismo intermitente limpo. Métodos: Questionário construído com base nas
\end{abstract}

1.Faculdade de Medicina de São José do Rio Preto - Pós-Graduação em Enfermagem em Estomaterapia - São José do Rio Preto (SP), Brazil. *Correspondence author: mirandarobertas@gmail.com

Received: Apr. 12, 2019 | Accepted: Mar. 09, 2020 
diretrizes da Associação Europeia de Enfermeiros Urológicos, aplicado a 18 enfermeiros de um hospital universitário, referência no atendimento do trauma raquimedular, a respeito de disfunção neurológica de trato urinário inferior e cateterismo intermitente limpo. Resultados: Os participantes apresentaram conhecimento expressivo a respeito da disfunção neurológica de trato urinário inferior e CIL. Houve erros quanto à técnica do CIL nos quesitos de indicação do uso luvas de procedimento, na lubrificação do cateter, coleta de culturas periódicas de urina, uso antibióticos e na necessidade de orientação antes da alta hospitalar. Conclusão: Apesar de a amostra demonstrar conhecimento em várias questões relacionadas ao tema, os erros indicam necessidade de capacitação e principalmente de conscientização quanto à responsabilidade de orientação antes da alta hospitalar.

DESCRITORES: Cateterismo urinário; Educação em saúde; Enfermeiro; Estomaterapia.

\section{RESUMEN}

Introducción: La lesión de la médula espinal provoca la imposibilidad de vaciar la vejiga, dejando al individuo expuesto al riesgo de infección recurrente del tracto urinario, reflujo vesicoureteral e incluso pérdida de la función renal. El cateterismo intermitente limpio es el método de elección para vaciar la vejiga en estos casos. A pesar de tener una técnica simple, su rendimiento debe estar bien orientado para evitar complicaciones como infecciones o traumatismos. La guía para la técnica debe realizarse durante el período de hospitalización debido a la lesión y la enfermera es responsable de esta acción. Objetivo: Evaluar el conocimiento de las enfermeras que trabajan en un hospital de atención de traumas en relación con la cateterización intermitente limpia. Métodos: Cuestionario construido sobre la base de las directrices de la Asociación Europea de Enfermeras Urológicas, aplicado a 18 enfermeras de un Hospital Universitario, una referencia en el tratamiento del trauma espinal, con respecto a la disfunción neurológica del tracto urinario inferior y el cateterismo intermitente limpio. Resultados: Los participantes presentaron conocimiento expresivo sobre la disfunción neurológica del tracto urinario inferior y el cateterismo intermitente limpio. Hubo errores con respecto a la técnica CIL en términos de indicar el uso de guantes de procedimiento, en la lubricación del catéter, la recolección de urocultivos periódicos, el uso de antibióticos y la necesidad de orientación antes del alta hospitalaria. Conclusión: Aunque la muestra demuestra conocimiento sobre varios temas relacionados con el tema, los errores indican la necesidad de capacitación y especialmente la conciencia de la responsabilidad de la orientación antes del alta hospitalaria.

DESCRIPTORES: Cateterismo urinario; Educación sanitaria; Enfermería; Estomatoterapia.

\section{INTRODUCTION}

Nurses feel every day the need to develop their scientific knowledge in search of answers to health problems in order to achieve excellence in care ${ }^{1}$. An effective way to achieve this goal is education in health, which provides the expansion of knowledge, with prospects of overcoming difficulties and gaining greater autonomy ${ }^{2}$. There are especially challenging health conditions for the nurse, and spinal cord injury is one of them. This is an overwhelming event in the life of the human being that causes damage to the structures of the spinal canal leading to changes in motor, sensory and autonomic functions, with consequent changes in the urinary pattern, in the phases of bladder filling and emptying. Spinal cord injuries are predominantly caused by trauma in automobile accidents, firearm injuries and falls ${ }^{3-4}$.

Again, mentioning the urinary system, in the spinal cord injury there is an interruption in the communication between the spinal cord and the central nervous system. This condition is defined as neurological lower urinary tract dysfunction (NLUTD) and may manifest as overactive bladder, with involuntary contractions in the urine storage phase, or underactive, with bladder distention and overflow, both with risk of urinary infection and vesicoureteral reflux ${ }^{5}$.

The NLUTD often results in high post-void residual (PVR) volume, so it requires catheterization for complete bladder emptying on a periodic basis. Clean intermittent catheterization (CIC) is the first technique of choice. Its technique requires the use of sterile gloves and antiseptics and can be used by patients or caregivers in the home environment ${ }^{6}$. The CIC procedure was first reported in scientific publications by Lapides et al. in 1972, who demonstrated that urinary tract infection (UTI) in NLUTD is caused by PVR and bladder distention, not necessarily by asepsis of the technique, thus proving to be more important to maintain a regularity of emptying than an aseptic technique ${ }^{7}$.

The steps to be followed are hygiene of the genital area and hands and lubrication and introduction of the catheter ${ }^{8}$. The independence in performing the procedure may not be achieved by patients with high injuries, but the possibility of improved motor function, i.e., improved hand mobility, arises after the first year 
of discharge when there is monitoring and counseling the patient on bladder control ${ }^{9}$.

Although it is the method of choice for bladder emptying and prevention of complications of NLUTD, $\mathrm{CIC}$ is not free of complications. Even with a relatively simple technique, it needs to be performed in a systematic way; for this, the patient must be trained by the nurse still in the period of hospitalization ${ }^{10}$. According to the Ministry of Health's guidelines for attention to the person with spinal cord injury, every patient with spinal cord injury needs to be directed to the $\mathrm{CIC}$ before discharge from hospital independently of the urodynamic study. Therefore, it is essential that the nurses who assist these patients are able to give such guidance ${ }^{3}$.

The educational process regarding the CIC is of great importance. The possibility of training in the hospital environment favors the observations of patients' acceptance and rejection, facilitates knowledge of their own body, location of the urethra, the importance of personal hygiene care, among other aspects ${ }^{11}$.

Given the scenario presented and the experience of the researchers, the following objective was outlined: identify whether the nurses working in hospitals that provide care to the person with spinal cord injury are prepared to guide the CIC. The publication of the results is expected to shed light on the subject in order to motivate the development of care protocols that ensure early and quality training for the patient in clean intermittent catheterization in order to avoid complications.

\section{METHODS}

Descriptive cross-sectional exploratory study with quantitative approach. The research was conducted at a university hospital in the state of Minas Gerais. Participated in the research nurses who worked in the hospitalization units that admit patients with spinal cord injury. The sample was nonprobabilistic and for convenience, the recruitment was carried out through the work schedule provided by the responsible nurse, the participating nurse was invited in person on the day of data collection, during working hours. Nurses on vacation, sick leave, maternity leave and activities from which they could not be absent at the time of the survey evaluation questionnaire were excluded.
Data were collected from February 6 to 22, 2019, after approval of the project by the Committee on Ethics and Research with Human Beings, with opinion No.3,114,560. The researchers went to the selected sectors after talking to the responsible nurse and approached each nurse in person with eligibility criteria for the study. All ethical and technical aspects of the research were explained in detail and the study questionnaire was applied only by signing the Free and Informed Consent Form. The questionnaire was prepared by the researchers for this survey based on international guidelines. The instrument was composed of data characterization of the sample and true and false questions about the steps and care in performing the technique. The quantitative variables were described by mean, standard deviation, minimum and maximum value. Categorical variables were described by absolute and relative frequency.

The analysis was made through absolute and relative frequencies and cross-references of the knowledge data of right and wrong for each item about the nurse's knowledge regarding the CIC, with age, formation, time and place of performance as the identification variables. All analyses were performed with the help of the statistical software Statistical Package for Social Sciences (SPSS), version 24.0.

\section{RESULTS}

Eighteen nurses participated in the study. Table 1 shows the sample profile data. It is noted that the sample was composed predominantly of women, with an average age of 37.6 years, with a post-graduation course, and an average of 11 years working in the field.

Table 2 shows the frequency and percentage of correct responses signaled by nurses for each content approached regarding clean intermittent catheterization.

It is observed that most nurses are aware that spinal cord injury results in an underactive or overactive bladder, and that both can lead to chronic urinary retention. Despite this result, a small percentage of the sample indicated that the CIC should be guided before discharge and more than half of the participants cited that it should be taught only after the result of the urodynamic study.

Most nurses agreed that the CIC can be performed by a caregiver committed to maintaining the recommended 
Table 1. Sample profile.

\begin{tabular}{|c|c|c|}
\hline Variable & Classification & Results $^{*}$ \\
\hline Age (years) & & $37.6 \pm 7.5(23-52)$ \\
\hline \multirow{2}{*}{ Gender } & Female & $14(77.8)$ \\
\hline & Male & $4(22.2)$ \\
\hline \multirow{2}{*}{ Graduate course } & No & $5(27.8)$ \\
\hline & Yes & $13(72.2)$ \\
\hline \multirow{3}{*}{ Sector of activity } & Surgical clinic 1 & $7(38.9)$ \\
\hline & Surgical clinic 2 & $6(33.3)$ \\
\hline & Surgical clinic 3 & $5(27.8)$ \\
\hline Working time as a nurse (years) & & $11 \pm 7.3(1-25)$ \\
\hline
\end{tabular}

*Standard deviation (minimum - maximum)

Table 2. Frequency and percentage of correct responses by nurses regarding clean intermittent catheterization.

\begin{tabular}{|c|c|}
\hline Question & Result n (\%) \\
\hline Consequences of spinal cord injury & $13(72.2)$ \\
\hline CIC guidance before discharge & $7(38.9)$ \\
\hline $\mathrm{CIC}$ indication after urodynamic examination & $10(55.6)$ \\
\hline Technique by the caretaker performed without touching & $15(83.3)$ \\
\hline Realization of the technique without infrastructure & $13(72.2)$ \\
\hline Hand hygiene with running water and soap & $16(88.9)$ \\
\hline Use of alcohol gel for hand hygiene & $14(77.8)$ \\
\hline Use of sterile gloves & $16(88.9)$ \\
\hline Use of procedural gloves & $6(33.3)$ \\
\hline No-touch technique by the caregiver & $14(77.8)$ \\
\hline Use of antiseptics in genital hygiene & $11(61.1)$ \\
\hline Genital hygiene with water and wet wipe & $12(66.7)$ \\
\hline Dermatitis for antiseptics & $13(72.2)$ \\
\hline Water soluble lubricating gel & $13(72.2)$ \\
\hline Lidocaine gel injection & $9(50.0)$ \\
\hline Lubrication with oily products & $17(94.4)$ \\
\hline Extension of lubrication of male/female catheter & $6(33.3)$ \\
\hline Slow introduction until urine drainage starts & $14(77.8)$ \\
\hline Penis angle for insertion & $15(83.3)$ \\
\hline To force the insertion in case of resistance & $16(88.9)$ \\
\hline Suprapubic precatheterization pressure & $12(66.7)$ \\
\hline Catheter size (08 to $12 \mathrm{Fr}$ ) & $12(66.7)$ \\
\hline Reuse of the catheter & $16(88.9)$ \\
\hline Indication for single use & $17(94.4)$ \\
\hline Optimal frequency of the technique & $13(72.2)$ \\
\hline Importance of the bladder diary in defining frequency & $18(100)$ \\
\hline Suspension of CIC if presence of spontaneous diuresis & $16(88.9)$ \\
\hline Reduction of intervals if urinary loss & $15(83.3)$ \\
\hline Reduction of water intake & $18(100)$ \\
\hline Urine culture and antibiotic therapy & $4(22.2)$ \\
\hline
\end{tabular}


frequency of the procedure, and that it should be performed even if infrastructure such as sinks and toilets are lacking. Hand hygiene has also been a high percentage of correctness, the majority indicated the recommendation for running water and liquid soap and that alcohol gel should not replace complete hygiene.

Most respondents agreed that there is no indication of the use of sterile gloves, but most were wrong not to indicate the performance of the technique without procedural gloves, even with hygienized hands. As for the indication of technique without touch by the caregiver, wearing gloves or gauze, most people agreed that this is the best recommendation.

Genital hygiene issues had a large percentage of successes. Most noted that there is no indication of use of antiseptics, that water or wet tissue are the options for all catheterizations and that frequent use of antiseptics can lead to local dermatitis. As for the lubrication of the catheter, the majority agreed that it should be with water soluble gel and that oily lubricants are not indicated; there were errors in the sense of not discouraging the injection of lidocaine in the urethra and also in the extension of lubrication of the catheter for men and women.

There was an expressive percentage of correct responses regarding the slow introduction of the catheter, angulation of the penis, not forcing the passage of the catheter and not doing suprapubic pressure before the catheterization. The data showed similar behavior in the catheter caliber items, no indication of catheter reuse.

The nurses also responded predominantly correctly regarding the ideal frequency for catheterization, the importance of the bladder diary to define the frequency, the nonsuspension of the procedure in the presence of spontaneous urination and the reduction of the interval in cases of frequent urinary loss.

All respondents agreed that there is no indication to reduce water intake and most were wrong to indicate periodic urine culture and antibiotic treatment in cases of bacteriuria.

The variables of characterization of the sample were crossed with the knowledge variables regarding the subject. For the comparison of the two groups, regarding quantitative variables, the Student's t-test was used for independent samples or the nonparametric MannWhitney test. The categorical variables were analyzed considering Fisher's exact test. To evaluate the association between two quantitative variables Spearman's rankorder correlations were estimated, values of $p<0.05$ indicated statistical significance. There was no significant association between the correct answers and the variables gender, sector of activity, time of formation and post-graduation.

\section{DISCUSSION}

The profile of the sample studied is consistent with the profile of Brazilian nursing, also demonstrated by other studies regarding predominant gender, mean age and education ${ }^{12,13}$.

The question of urological consequences of spinal cord injury had a good percentage of success, showing that the nurses know that the patients attended will have the urination pattern altered. Urological changes caused by spinal cord injury are one of the greatest concerns of rehabilitation professionals, because inadequate bladder function, when treated incorrectly, causes unfavorable conditions such as urinary infection, bladder stones, penoscrotal fistulas, vesicoureteral reflux, hydronephrosis and can even lead to loss of renal function ${ }^{3}$.

An intriguing fact, perhaps the most worrying, was the orientation of the pre-discharge CIC. Few interviewees agreed that it is mandatory, even though they agreed that the patients will present important dysfunctions from the spinal cord injury. In this aspect, the Guidelines for Attention to the Person with Spinal Cord Injury indicate that the CIC should be instituted on a mandatory basis, regardless of the early performance of the urodynamic examination, from hospital discharge, and the orientation of the patient or caregiver before discharge ${ }^{3}$.

Regarding the accomplishment of the technique by a caregiver, predominantly with correct answers by the sample, the Brazilian Society of Urology and the European Association of Urological Nurses emphasize the need to train patients, relatives and caregivers on the correct procedure of clean intermittent catheterization in order to avoid complications. In the cases of patients without manual agility, due to loss of movement and lack of adaptation to auxiliary devices or due to learning difficulty, the presence of a caregiver to be trained to perform the technique is essential ${ }^{14}$. An applied research in a hospital in the countryside of São Paulo with 141 users of CIC showed in its result that half of these 
patients need help from relatives, caregivers or primary care health professionals to perform the procedure ${ }^{15}$.

The majority of the sample agreed that the CIC should be performed even without infrastructure, to maintain its optimal regularity and no storage of urine above $500 \mathrm{ml}$. Users of CIC should be attentive to the question of infrastructure, however they should not refrain from doing the CIC due to lack of a clean location, being away from home or on a travel; because regular catheterization acts in the prevention of infections and other consequences related to stagnant diuresis ${ }^{16}$.

Regarding hand hygiene with soap and water, no substitution by alcohol gel and no need for sterile gloves, most of them responded correctly and showed to know the subject, but on the topic of using procedure gloves, the majority responded that it is necessary, which can burden and hinder the procedure. The recommendation for hand hygiene with water and soap, preferably liquid soap, is cited by several authors ${ }^{6,8,14}$. In the absence of infrastructure such as sinks, they guide to carry water in a bottle or other utensil to wash hands and the urethral meatus ${ }^{8}$. There are professionals who indicate the use of the wet wipe in the sanitization of the urethra, as an alternative in the lack of other resources ${ }^{14}$. No references were found indicating the use of alcohol gel as a substitute for water and soap in the $\mathrm{CIC}$ technique, but it is worth considering the strong campaign conducted by the hospital infection control services, ensuring its action in the absence of dirt and with the need for friction. The technical reference manual for hand hygiene not related to CIC states that hygiene can be performed by rubbing the hands with alcohol solution or with water and soap, the two techniques being able to leave the patient free of contaminations of microbiota ${ }^{17}$.

As for the use of gloves, sterile gloves are recommended for aseptic technique in hospital environment. Procedure gloves can be worn in the home environment. Their use, however, is dispensable in the clean technique, maintaining the previous hygienization of the hands. The only exception where clean intermittent catheterization should be performed with the rigor of the sterile technique is in immunosuppressed neuropathic patients ${ }^{14,15}$.

The participants agreed that the no-touch technique can be performed by the caregiver. The no-touch technique consists of introducing the catheter without touching the portion that will come into contact with the bladder. It is the most suitable technique and the ready-to-use catheters (lubricated and hydrophilic) are the most suitable for the execution $^{6}$. An integrative review of articles on CIC best practices conducted from 2010 to 2015 demonstrated that the CIC procedure with the no-touch technique reduces the likelihood of urinary tract infection compared to sterile intermittent catheterization ${ }^{18}$.

There is no indication of the use of antiseptic for genital hygiene before the CIC and more than half of the participants responded correctly. Studies show that the use of antiseptics causes dermatitis, which is in line with the response of the nurses surveyed. The most correct form of hygiene of the urethra is the cleaning with a wet gauze with water, if there is no visible dirt, or wet wipe making circular movements two or three times before the introduction of the catheter, remembering that the genital area must be sanitized with soap and water twice a day at the time of the catheterization; and more than half of the sample also responded correctly ${ }^{6,8,19}$. A systematic review with metaanalysis sought to compare the efficacy of urethral meatus cleaning before bladder catheterization with water or saline solution and antiseptics and proved that there was no statistically significant difference when comparing the two methods in the question of UTI prevention. Therefore, they suggested revising guidelines to reduce costs and prevent allergies that can be caused by antiseptics ${ }^{20}$.

Most of those surveyed indicated as correct the use of water-soluble gels for lubrication before CIC, agreeing with the literature that indicates the use of gel lubrication in uncoated catheters, the lubricants indicated are water soluble gels. In the clean technique it is not necessary the use of sterile gels ${ }^{8,14,21}$. The literature indicates the use of hydrophilic lubricants; therefore, the use of oily products is contraindicated. Oily products, because they are hydrophobic, are detached from the catheter when they come into contact with urine and leave residues inside the bladder, thus favoring the formation of bladder stones ${ }^{8}$.

Half of the interviewees were wrong to point out that the lidocaine injection before catheterization is correct. Lidocaine injection is not indicated due to frequent use, which may result in systemic absorption ${ }^{6}$, in addition to mobilizing the distal microbial flora to the proximal portion of the urethra. An integrative review of the literature regarding the application of $2 \%$ lidocaine in male urinary catheterization showed that no statistically significant difference was observed regarding the instillation or not of intraurethral lidocaine. Nor has it been demonstrated that the analgesic activity of lidocaine is 
efficient, and there is no consensus on how long to wait to introduce the catheter or whether it should be introduced immediately. There are gaps in the literature on the subject, and new studies are suggested ${ }^{21}$.

Although there are no publications on the subject, there is a consensus among professionals to not suggest lidocaine injection in CIC for two reasons. The first reason is the frequent displacement of the distal flora of the urethra to the proximal region. The second is related to lidocaine itself, because it is not known what the absorption by the urethral mucosa would be, considering the large number of procedures throughout life. Reasons that justify the absence of lidocaine injection guidance in CIC consensus and guidelines.

Most participants were right about the slow introduction of the catheter, penis angulation and contraindication to force the introduction in case of resistance. The slow introduction of the catheter as well as avoiding forcing the passage if resistance is experienced are essential care to prevent trauma and the development of urethral stenosis ${ }^{14}$. Prostate enlargement or involuntary sphincter contraction can cause resistance, in the case of the prostate, and a slight reduction in penis angulation can help; as for sphincter contraction, the catheter should be kept in the same position, awaiting its relaxation ${ }^{8,14}$.

The majority of the sample was correct for contraindication of abdominal pressure or suprapubic compression precatheterization. Retrospective analysis of medical records of patients with spina bifida and underactive bladder showed that Valsalva maneuver is harmful due to high bladder pressure and high pressure applied to the perineum with abdominal effort $^{22}$. Qualitative and descriptive research applied in family members of children with neurogenic bladder and in use of CIC observed the adoption of inadequate techniques such as abdominal massage for urination ${ }^{23}$.

As for the ideal catheter caliber, it should be of sufficient diameter to allow urine free flow in an acceptable time, with as little caliber as possible so as not to cause injury to the urethra according to the European Association of Nurses in Urology guideline ${ }^{6}$. The participants accurately marked the indication of sizes from 8 to $12 \mathrm{Fr}$ for adults.

Reuse of the catheter is not recommended and most nurses answered this statement correctly. A literature review on UTIs and costs related to the single use or reuse of different catheters from 2014 to 2018 confirmed that there is not enough safe scientific research to guide reuse of catheters. Reusing catheters exposes the user to catheter hygiene techniques that have not been tested in consistent research. The catheter reuse time was also not defined ${ }^{24}$. Authors of another bibliographical review considered the prescription of a single catheter for each procedure as a measure to prevent infection $^{16}$. They reinforce the lack of satisfactory research on an ideal method for cleaning multiple-use catheters, which is the reason for not recommending $\mathrm{it}^{16,24}$.

A large percentage of the surveyed nurses answered that the ideal frequency of performing the technique should be maintained and pointed out the importance of the bladder diary to define these intervals. The specialist health professional should indicate the number of catheterizations to be performed in 24 hours according to information on daily fluid intake and volume of drained urine, data extracted from the bladder diary. The volume of diuresis at each procedure should not exceed $400 \mathrm{ml}$, higher volumes lead to risk of UTI by distention ${ }^{6,16}$.

It is not advisable to reduce the water intake so that there is no change in the color and odor of the urine. All participants assertively agreed with this statement. Water intake is considered one of the best practices for prevention of urinary tract infection ${ }^{16}$. If hydration is efficient, urine is diluted and maintains constant diuresis. The daily intake volume indicated is $25-35 \mathrm{ml} / \mathrm{kg}$. The abusive ingestion of liquids, on the other hand, increases the chance of bladder hyperdistention and overflow, signaled by incontinence. The person with NLUTD may present urinary loss due to overflow or detrusor hyperactivity. The presence of spontaneous diuresis does not indicate the possibility of suspension of the CIC, a question agreed upon by a large number of participants.

A small part of those surveyed agreed that periodic urine culture and antibiotic therapy, if bacteriuria, is not indicated. Patients with CIC have a colonized urinary tract, so urine cultures tend to be positive. The UTI should be investigated for signs and symptoms that patients should be advised to recognize. The culture in these cases serves only to guide the choice of drug treatment ${ }^{3,6,14}$.

\section{CONCLUSION}

The sample studied showed considerable knowledge about neurological lower urinary tract dysfunction and clean intermittent catheterization. Questions regarding the indication of the procedure without gloves, no need 
for periodic urine culture and treatment for asymptomatic bacteriuria, contraindication of injecting lidocaine into the urethra on a regular basis and the amount of lubricant in the catheter for insertion were items in which less than half of the sample was correct, indicating the need for updating activities.

The response with a large number of errors that proved more worrying was regarding the patient's orientation to CIC before discharge. The majority of the sample did not mark this statement as true, with the location of the sample being a reference in the care of the spinal cord injury and every nurse should be aware and safe for orientation during the period of hospitalization.

It is necessary to discuss the topic among services that provide such services in order to shed light on the need for training programs and implementation of assistance protocols.

\section{ACKNOWLEDGMENTS}

Acknowledgements to Faculdade de Medicina de São José do Rio Preto and Hospital das Clínicas of the Universidade Federal de Uberlândia.

\section{AUTHOR'S CONTRIBUTION}

Conceptualization, Assis GM, Miranda RS, Dornellas ACL,Messias AMB, Batista VT, and Gomes Jj; Methodology, Assis GM and Batista VT; Data Collection, Miranda RS; Writing - Original Draft, Assis GM, Miranda RS, Dornellas ACL, Messias AMB and Batista VT; Writing - Review \& Editing, Assis GM, Miranda RS, Dornellas ACL, Messias $\mathrm{AMB}$ and Batista VT; Supervision, Assis GM and Gomes JJ.

\section{REFERENCES}

1. Antônio V. Importância do enfermeiro especialista em enfermagem de reabilitação na promoção do autocuidado eliminação vesical à pessoa/família com paraplegia resultante de lesão vertebro medular. Santarém. Dissertação [Mestrado Enfermagem de Reabilitação] - Instituto Politécnico de Santarém, Escola Superior de Saúde; 2018.

2. Sousa LB, Torres CA, Pinheiro PNC, Pinheiro AKB. Práticas de educação em saúde no Brasil: a atuação da enfermagem. Rev Enferm UERJ. 2010;18(1):55-60.

3. Brasil. Ministério da Saúde. Diretrizes de atenção à pessoa com lesão medular. 2ª ed. Brasília (DF): Ministério da Saúde; 2015.

4. Dorsher PT, McIntosh PM. Neurogenic bladder. Adv Urol. 2012;2012(816274):1-16. https://doi.org/10.1155/2012/816274

5. Mckibben MJ, Seed P, Ross SS, Borawski KM. Urinary tract infection and neurogenic bladder. Urol Clin North Am. 2015;42(4):527-36. https://doi.org/10.1016/j.ucl.2015.05.006

6. Vahr S, Cobussen-Boekhorst H, Eikenboom J, Geng V, Holroyd $\mathrm{S}$, et al. Evidence based guidelines for best practice in urological heath care. Catheterisation urethral intermittent in adults. Dilatation, urethral intermittent in adults. Arnhem: European Association of Urology Nurses; 2013.

7. Lapides J, Diokno AC, Silber SJ, Lowe BS. Clean, intermittent self-catheterization in the treatment of urinary tract disease. J Urol. 1972;107(3):458-61. https://doi.org/10.1016/S00225347(17)61055-3

8. Assis GM, Fraga R. Cateterismo intermitente limpo. Manual ilustrado de orientação ao usuário (adulto). Curitiba: Universidade Federal do Paraná - Hospital de Clínicas; 2015.
9. Elliott CS, Zlatev D, Crew J, Shem K. Do appreciable changes in the upper extremity motor capability to perform clean intermittent catheterization come about with time after traumatic spinal cord injury? Neurourol Urodynam. 2019;38(3):975-80. https://doi.org/10.1002/nau.23943

10. Alavinia SM, Omidvar M, Farahani F, Bayley M, Zee J, Craven BC. Enhancing quality practice for prevention and diagnosis of urinary tract infection during inpatient spinal cord rehabilitation. J Spinal Cord Med. 2017;40(6):803-12. https:// doi.org/10.1080/10790268.2017.1369216

11. Garcia F, Altamirano B, Machado C. Vaciado vesical a traves del cateterismo intermitente limpio. Medicina Infantil. 2016;23(2):192-3.

12. Araújo MAN, Lunardi Filho WDD, Alvarenga MRM, Oliveira RD, Souza JC, Vidmantas S. Sociodemographic profile of nurses of the hospital network. J Nurs UFPE on line. 2017 Nov;11(Supl. 11):4716-25.

13. Machado MH, Aguiar Filho W, Lacerda WF, Oliveira E, Lemos W, Wermelinger $\mathrm{M}$, et al. Características gerais da enfermagem: o perfil sócio demográfico. Enferm Foco. 2015;7:9-14. https:// doi.org/10.21675/2357-707X.2016.v7.nESP.686

14. Truzzi JC, Canalini AF, Prezotti JA, Resplande J. Recomendações SBU 2016. Cateterismo vesical intermitente. Rio de Janeiro (RJ): Sociedade Brasileira de Urologia; 2016.

15. Santos RCR, Fumincelli L, Nassiff A, Souza Júnior VD, Jorge BM, Mazzo A. Neurogenic bladder patient: intermittent urinary catheterization and intestinal care. J Nurs UFPE on line. 2015;9(Supl. 7):8953-60. 
16. Lamin E, Newman DK. Clean intermittent catheterization revisited. Int Urol Nephrol. 2016;48(6):931-9. https://doi. org/10.1007/s11255-016-1236-9

17. World Health Organization (WHO). Manual de referência para técnica para a higiene das mãos. Genebra: WHO; 2009.

18. Amorin RT, Cavalcante TB, Diniz BPO, Miranda SM, Sousa ARA, Rocha AJSC. Cateterismo uretral intermitente em ambiente hospitalar: revisão integrativa. In: XII Congresso Brasileiro de Estomaterapia 2017; 2017 nov. 12-15; Belo Horizonte (MG). Belo Horizonte: Sobest; 2017.

19. Brasil. Governo do Distrito Federal. Secretaria de Estado de Saúde. Portaria SES-DF nº 791 de 26 de julho de 2018. Protocolo de Atenção à Saúde: Atendimento ao Usuário com Necessidade de Cateterismo Vesical. Brasília (DF): Diário Oficial do Distrito Federal 7 ago. 2018; 6-7 [citado em 19 nov 2019]. Disponível em: http://uww.buriti.df.gov.br/ftp/diariooficial/2018/08_Agosto/ DODF\%20149\%2007-08-2018/DODF\%20149\%2007-082018\%20INTEGRA.pdf

20. Cunha M, Santos E, Andrade A, Jesus R, Aguiar C, Marques F, et al. Eficácia da limpeza ou desinfeção do meato urinário antes da cateterização urinária: revisão sistemática. Rev Esc Enferm USP. 2013;47(6):1407-13. https://doi.org/10.1590/S0080623420130000600023

21. Santos RP, Tres DP, Rosin J, Peres RR, Carvalho ARS. Aplicação lidocaína gel a 2\% no cateterismo urinário: revisão integrativa de literatura. Revista Varia Scientia - Ciências da Saúde. 2016;2(2):165-73.

22. El Akri M, Brochard C, Hascoet J, Jezequel M, Alimi Q, Khene Z-E, et al. Risk of prolapse and urinary complications in adult spina bifida patients with neurogenic acontractile detrusor using clean intermittent catheterization versus Valsalva voiding. Neurourol Urodynam. 2019;38(1):269-77. https://doi.org/10.1002/nau.23844

23. Antonio S, Pacheco STA, Gomes MPF, Reis AT, Rodrigues BMRD, Souza SM. Cateterismo intermitente limpo em crianças com bexiga urinária neurogênica: o cuidado do familiar no domicílio. Rev Enferm UERJ. 2015;23(2):191-6. https://doi.org/10.12957/ reuerj.2015.16493

24. Saadat SH, Shepherd S, Asseldonk BV, Elterman DS. Clean intermittent catheterization: single use vs. reuse. Can Urol Assoc J. 2019;13(2):64-9. https://doi.org/10.5489/cuaj.5357 